\title{
Exploring nudist festival attendance at a Mexican beach: a tourist motivation approach
}

\section{Carlos Monterrubio}

To cite this article: Carlos Monterrubio (2019) Exploring nudist festival attendance at a Mexican beach: a tourist motivation approach, Journal of Travel \& Tourism Marketing, 36:5, 583-594, DOI: 10.1080/10548408.2019.1604295

To link to this article: https://doi.org/10.1080/10548408.2019.1604295

曲 Published online: 14 Apr 2019.

Submit your article to this journal

View Crossmark data $₫$ 


\title{
Exploring nudist festival attendance at a Mexican beach: a tourist motivation approach
}

\author{
Carlos Monterrubio (1)
}

Texcoco Campus, Autonomous University of the State of Mexico, Estado de México, Mexico

ABSTRACT

Motivations to attend nudist festivals and their association with tourist motivation factors have been largely unexplored. Based on qualitative interviews with nudist tourists, this study explored these individuals' motivations for attending a nudist festival in Mexico. The findings reveal a complex amalgamation of both festival and tourism motivation constructs. Based on the escape-seeking dichotomy and push-pull framework, data analyses revealed that the interpersonal festival motivations are more significant than personal factors are and the pull factors of the event-hosting destination can dominate over festival factors. The findings have important practical implications for nudism festival organisers.
ARTICLE HISTORY

Received 18 December 2018 Revised 23 February 2019 Accepted 1 April 2019

KEYWORDS

Festival motivation; tourist motivation; nudism festival; nudism; naturism; nudist motivation; escape-seeking; push-pull; Zipolite; Mexico

\section{Introduction}

Motivations can be understood as internal factors that arouse, direct and integrate individuals' behaviours, so they are the starting point for decision processes (Crompton \& McKay, 1997). Tourists' decisions involve multiple motivations (Crompton, 1979; Mansfeld, 1992), and, according to Crompton and McKay (1997), these decisions may take place at both the individual and aggregate levels of analysis. Various specific requirements such as a need to escape from personal routines are significant at the individual level, while diverse needs and experiences derived from interpersonal interactions are important at the aggregate level.

Crompton and McKay (1997) argue that gaining a better understanding of festival motivations is necessary for three main reasons. First, understanding why people visit an event and what their expectations are informs the choice of services and products to be developed. After identifying motivations, practical settings and contexts of events can be adjusted to ensure they fulfil attendees' needs. Second, knowing visitors' motivations helps to ensure their satisfaction since, if their needs and motivations are addressed, satisfaction will naturally follow. Last, identifying motivations is essential to understanding visitors' decision processes, which facilitates marketing efforts.

Research on festival and event motivations has produced findings of sociological relevance. Maeng, Jang, and $\mathrm{Li}$ (2016) report that festivals are inward-looking events for local communities, so these events should be studied inwardly, that is from these communities' perspectives. The cited authors suggest that analyses of festival motivations should consider the varied social environments of individuals, festival diversity and the sociological, psychological and anthropological characteristics inherent in festival motivations. Thus, in addition to psychological factors, festivals involve the social and cultural aspects of both local communities and visitors. These aspects, therefore, need to be considered in any analysis of visitors' motivations. Because festival attendees quite likely are seeking cultural enrichment and socialisation (Crompton \& McKay, 1997), identifying their motivations for going to festivals and events with cultural components can also enhance the social interactions between - and cultural dimensions shared by - visitors and locals.

Chang and Yuan (2011) argue that motivations may not be homogenous across different types of festivals, which requires differentiation in marketing strategies. This could be the main reason why research on festival motivation has focused on a wide variety of festivals, including religious celebrations and cultural, community, aboriginal, wine, food, music, art, regional and experiential festivals (Maeng et al., 2016). However, little is known about motivations for festivals in which socially condemned behaviours and lifestyles are the core theme or attraction.

In particular, attendance motivations for nudism festivals have remained largely ignored by tourism, festival and event motivation studies. More specifically, the

CONTACT Carlos Monterrubio, jcmonterrubioc@uaemex.mx E Autonomous University of the State of Mexico, Texcoco, Mexico, Av. Jardín Zumpango $\mathrm{S} / \mathrm{N}$, Fracc. El Tejocote, Texcoco, Estado de México, 56259, Mexico

๑ 2019 Informa UK Limited, trading as Taylor \& Francis Group 
existing literature does not appear to include research exploring the underlying reasons for attending nudist festivals and events. As a social and personal practice, nudism has unique physical, psychological, emotional, medical, moral and social benefits (Barcan, 2015; West, 2018). However, this practice has been socially condemned by many individuals who consider it a deviation from societal norms, as well as consisting of erotic acts of immodesty associated with sexuality (Andriotis, 2010).

From a benefit versus social disapproval binary perspective, some questions remain unanswered:

- How significant are festivals and holidays for nudists?

- What are the personal and interpersonal factors that lead individuals to attend nudist festivals?

- How closely related are nudist festival motivations to more general tourism motivations?

Exploring both intrinsic and extrinsic motivation factors in nudist festival attendance and their relationship to tourism motivations can help develop a more contextually diversified understanding of festival motivations. In addition, this can provide practical implications for festival developers regarding nudist tourists' satisfaction and product design. This study, therefore, sought to contribute to answering these questions.

Based on their review of festival motivation studies, Maeng et al. (2016) observe that these have been largely derived from studies related to tourism motivations rather than from indicators exclusive to festivals. The cited authors thus argue that tourist motivation studies have not been suitably adjusted to examine festival attendance patterns effectively. This could be true for small festivals in which travel and escapeseeking motivations are not particularly important components. However, this limitation may not be applicable to research on festivals with a quite substantial tourism dimension, especially when this is combined with the tourist pull factors of the event-hosting destinations. In these cases, both the festival and destination become attractors for tourists.

The present study aimed to provide empirical evidence of these factors by exploring nudist tourists' motivations for attending a nudist festival in Mexico. Festivals in Mexico, in general, have been widely excluded from general debates about and construction of knowledge in festival and event research. By incorporating evidence from events in contexts not previously explored, a broader and more diverse understanding of festival and event motivations can be gained.

\section{Tourism and festival motivations}

Most studies of festival and event motivations have been undertaken within the theoretical framework of travel and tourism motivation research. This has been rationalised on the basis of the leisure, escape-seeking, mobility and sociocultural dimensions shared by both tourism and events. Maeng et al. (2016) thus observe that, in empirical research, most motivation factors for festival attendance have been borrowed from tourist motivation studies. The earliest contributions to a sound understanding of tourist motivations were provided by Crompton (1979), Dann (1977) and Iso-Ahola (1980). These and later investigations (Snepenger, King, Marshal, \& Uysal, 2006) identified individuals' motivations for tourism and concluded that these include both psychological and social domains. Beginning with the earliest studies, the search for escape, self-exploration, relaxation, prestige, regression, kinship-enhancement, social interaction, novelty and education has been viewed as major motivation factors for tourists.

Travel and tourism motivation research has been conceptually grounded on both the escape-seeking dichotomy and push-pull framework (Uysal, Li, \& Sirakaya-Turk, 2008). With regard to the former dichotomy, escape elements refer to intrinsic rewards and opportunities to break away from routines and everyday environments. Both escaping and seeking can be experienced simultaneously, and they can include personal and interpersonal components. Through tourism, individuals thus seek recreational opportunities in order to escape from routine activities, leave behind personal and/or interpersonal difficulties and gain personal and/ or interpersonal rewards. Previous research applying the escape-seeking dichotomy has identified four dimensions in leisure and tourism motivations: personal search, personal escape, interpersonal search and interpersonal escape (Iso-Ahola, 1982).

Tourist motivations have also been explained based on individual needs and destination attributes. The push-pull framework's main premise is that individuals are pushed to participate by internal imbalances and the need to seek an optimal level of arousal. This framework further postulates that, at the same time, individuals are pulled by specific destinations' offers (Dann, 1977). Thus, while push motivation factors are perceived as more general and likely to be addressed by a variety of different activities, pull factors are thought to be characteristics specific to each destination or event (Snepenger et al., 2006). As a result, motivations are viewed as either behavioural or cognitive constructs, which are connected to specific situations or 
unique settings (Chang \& Yuan, 2011). Although no single theory of tourist motivation can be expected to explain fully the multiple dimensions of tourists' motivations and behaviours (Crompton \& McKay, 1997), both the escape-seeking and push-pull theories have proved useful for understanding the motivations of festival and event tourists (Li \& Petrick, 2006).

However, measuring festival motivations based on previous tourism motivation research has been shown to lead organisers to adopt inappropriate festival designs, so studies of festival motivations need to be conducted differently (Maeng et al., 2016). In practice, this approach can be applied with ease to festivals whose characteristics are clearly differentiated from the host destinations' tourism dimensions. However, when both the festival and destination share similar or the same pull motivation components, researching these becomes quite complex as both the event and destination have their own attraction factors.

The theoretical and conceptual findings of tourism motivation studies have without doubt provided considerable insight into festival motivations, and their contributions should not be ignored. Nonetheless, more festival-specific research needs to be undertaken in order to gain a deeper understanding of motivation factors unique to festivals and similar events. In addition, other methodological approaches need to be adopted, particularly those in which motivations are (un)named and explained using visitors' own words rather than through predetermined literature-derived motivation factors. This will produce more contextualised and subjectivity-based understandings of motivations to attend festivals.

Previous studies of eventgoers' motivations have explored not only the reasons visitors go to events but also visitors' demographic profiles, as well as their satisfaction and behavioural characteristics (Li \& Petrick, 2006). The present research did not conduct a detailed review of the literature on festival motivations as other studies have conducted reviews focused on this topic (Getz, 2010; Li \& Petrick, 2006; Maeng et al., 2016). Some relevant broad conclusions, however, were used as a starting point in the current research.

In their review of festival and event motivation research, Li and Petrick (2006) summarised selected studies, revealing that these motivations have often been categorised under specific and evidently well-established domains. For example, Crompton (1979) identified seven sociopsychological motivation factors: novelty, socialisation, prestige, status, rest and relaxation, regression, education value and/or intellectual enrichment and enhancement of kinship and relationships and/or family togetherness. Crompton and McKay (1997) went on to explore motivations across a substantial number and diverse range of events within a large festival and concluded that festival motivation measurement instruments should incorporate six factors. These are cultural exploration, novelty and/or regression, recovery of equilibrium (i.e. rest and relaxation and/or escape), known-group socialisation, external interaction and/or socialisation and family togetherness (i.e. enhancement of kinship relationships).

The most recent review of research on festival motivation factors was undertaken by Maeng et al. (2016). The cited authors' meta-analysis of 46 specialised articles revealed that socialisation, family togetherness, escape, novelty, cultural exploration, excitement, festival attraction, entertainment, learning and relaxation have been mentioned quite frequently by previous research on festival and event motivations. While Maeng et al. (2016) concluded that some of these factors are not exclusive to festivals but apply to tourism in general, considering these motivation factors has helped researchers to explain not only local but also tourism dimensions of festival and event motivations. Several other studies (Chang \& Yuan, 2011; Fisher \& Price, 1991; Hanqin \& Lam, 1999) have confirmed that motivations to participate in festivals, events and tourism are intertwined and characterised by multiplicity and context specificity.

\section{Nudism}

Social nudity has been traced back to ancient Greece, but it was not until the 1920s that nudity was widely practised in European societies - mainly in Germany, France, Switzerland and the United Kingdom (Clarke, 1982). The practice of nudism has long been justified by its multiple benefits. Early nudists condemned clothing as dangerous to humans' physical, psychological, sexual and moral health. From a sociological point of view, clothing can be seen as emblematic of class distinctions and part of oppressive psychological and sexual regimes. Nudism practitioners have thus long regarded social nudity as a medical, philosophical and political movement that seeks to remediate social harms such as gender, class and racial inequalities (Barcan, 2015). Furthermore, nudism has been used as an alternative treatment based on exposing the body to the natural elements (Barthe-Deloizy, 2003). Recent psychological studies have also found that participation in naturist activities promotes a more positive body image, higher self-esteem and greater life satisfaction (West, 2018).

Nudism has been conceptualised as a leisure activity, cultural practice (Jaurand, 2006) and lifestyle (Barcan, 
2015). The definition of nudism as a lifestyle is largely derived from naturist philosophy. Naturism's fundamental ideal is that nature and its elements are always medically beneficial to humans (Barthe-Deloizy, 2003), thereby emphasising the non-sexual and family components of public nudity (Schoemaker, 2006). Nudist activities have been identified with naturism's explanation and legitimatisation of nudists' behaviour as nonsexual and thus nondeviant (Schoemaker, 2006). Within naturist philosophy, sexual talk is, therefore, taboo, and body contact is discouraged, especially in naturist clubs, in which the family element is predominant (Daley, 2005).

However, public nudity does not always subscribe to naturist philosophy, as nudity can be connected to voyeurism, exhibitionism and other sexual practices, including intercourse in public spaces (Andriotis, 2010; Douglas, Rasmussen, \& Flanagan, 1977; Schoemaker, 2006). As a result, Barcan (2015, p. 2) reports that:

Despite nudists' fervent belief in the moral, social, and psychological benefits of their practice, nudism has widely been seen as a strange, even deviant, practice, and nudism has always had to fend off accusations - both jocular and outraged - of 'perversion' and licentiousness.

Despite its growing popularity, acceptance and practice, nudism has been significantly neglected by academia (Schoemaker, 2006). Many decades have passed since the first empirically sound writings on nudism were published (Merrill \& Merrill, 1931), and evidence of its sociological, political, medical and psychological dimensions has long been available (Douglas et al., 1977; Jaurand \& de-Luze, 2004; West, 2018). However, nudism as a social phenomenon and its relationship to other social experiences such as festivals and tourism remain largely unexplored, particularly in developing countries.

Organised nudist events can function as an important catalyst for tourism. However, virtually nothing is known about the sociocultural and psychological dimensions including motivation factors - of these events. Events in which public nudity is a core component, such as World Naked Bike Rides (WNBR), may provide an idea about the significance of social nudity for participants. Although WNBR primarily aimed to raise awareness about automobile traffic and oil dependence, and to expose the dangers faced by cyclists and pedestrians (WNBR, 2006), they now provide participants with feelings of freedom, happiness and body confidence (Carter, 2018). However, WNBR's social and environmental goals make participants' motivations different from those in nudist events in which nudity is the central component (i.e. not only the means but also the end).

Valuable empirical findings on the practice of social nudity and its association with events, however, can be extracted from tourism studies. Research has been done on locals and nudists' perceptions of social nudity and each other in Mexico (Monterrubio, 2019), the characteristics of the European naturist camping market (Jurdana, Milohnic, \& Cvelic-Bonifacic, 2009), nude beaches functioning as gay erotic oases (Andriotis, 2010) and antinomians' nude activities (Andriotis, 2013). The results suggest that travelling for nudism purposes is proliferating as a social phenomenon and it thus has significant sociocultural implications that deserve empirical research that addresses the associated theoretical and practical issues.

Within a tourism context, the cognitive and social constructs of nudism as motivation factors still remain largely unexplored. Based on a survey of 1,508 nudists belonging to naturist and/or nudist associations in different parts of the world, Andriotis's (2016) study is one of the few although not the only - to focus exclusively on nudists' motivations as these relate to tourism. The cited author found that the term nudism can be interpreted as both a social or recreational activity and a reflection of a lifestyle with ideological and philosophical roots (i.e. naturism).

Andriotis (2016) proposed the concept of "natourism" to refer to travel in which naturists seek out not only recreational activities and affirmation of their lifestyle but also stereotypical tourism activities such as cultural events and shopping, as well as good weather. In addition to testing the validity of this concept, the cited author also identified four motivation factors for nudism in tourism contexts. The first is naturalism and relaxation since, through social nudity, individuals seek to relax mentally and physically. The second factor is sexuality given that social nudity can be performed as an act of bodily disclosure and exposure and as a search for sex partners. The third is stereotypical travel motivations since, in addition to nude activities, individuals seek ancillary or peripheral activities such as cultural experiences. The last factor is personal and family motivations as benefits are expected at the personal and family levels.

Andriotis's (2016) findings help clarify why nudists travel for leisure purposes but not what the intrinsic and extrinsic motivation factors are for attending nudist festivals. Research on nudist festival motivations is needed to develop a more encompassing theoretical understanding of festival motivations and identify management and practical implications useful to nudist festival developers.

\section{Study aims and context}

This study sought to explore empirically nudist tourists' motivations for attending a nudist festival by examining the 2017 Zipolite Nudist Festival in Mexico. Two specific objectives were pursued: 1) to explore the nudist 
festival attendees' sociodemographic profile and 2) to examine nudists' festival motivation factors and their association with tourism motivations. The research was based on both the escape-seeking dichotomy and push-pull framework in order to understand visitors' motivations in terms of personal and interpersonal as well as intrinsic and extrinsic - components.

The nudist festival took place in Zipolite, a tourism destination with the only nude-optional beach in Mexico. Because studies of festival motivations should consider local communities' sociocultural conditions and needs and the intrinsic motivation and characteristics of each festival (Maeng et al., 2016), a detailed description of the event-hosting community was also compiled. Zipolite is in a remote rural location, so it has experienced only small-scale tourism development. The town has an average annual temperature of $30^{\circ} \mathrm{C}$. Tourism currently is Zipolite's main economic activity. Nudism in tandem with a hippie lifestyle has been part of this town's offer since the inception of tourism in the area. In the beginning, European visitors were the main nudist tourist group in Zipolite, but the number of domestic nudist tourists and other visitors drawn by curiosity have increased in recent years.

Zipolite has been widely publicised as the only "official" nude beach in Mexico (see www.mexicodestinos. com), and new strategies have been implemented to increase nude tourism in the area. In 2016, Zipolite hosted the VI Latin American Naturist Encounter known in Spanish as "ELAN 6". It hosted the Zipolite Nudist Festival in 2017 and 2018.

The 2017 Nudist Festival was selected as the research context best suited to meet the objectives of this study. The Nudist Festival was a three-day event (i.e. 3-5 February) that sought to promote internationally both nude tourism and Zipolite as the only nude beach in Mexico. The festival also aimed to foster greater acceptance of the human body and to reject the idea that nudism is wrong or perverse. Activities included, among others, nude yoga, talks on nudism, body painting, traditional folk dances and live music. The event attracted a large number of visitors, which was reflected in accommodation establishments' high occupancy levels (EFE, 2017). While some activities were meant for nudists only (e.g. yoga and body painting), others were open to the general public (e.g. live music and traditional folk dances). Therefore, the festival offered both nudismexclusive and regional cultural components.

The event was organised by local community members - especially representatives of the local tourism industry - and the Federación Nudista de México (FNM) (Mexican Nudist Federation). As with other nudist events in the country, the FNM played an important role in the festival's national and international promotion and offered travel advice to its members and other interested individuals from Mexico and abroad. The FNM, in general, seeks to foster social and family nudism, promote acceptance of the human body and support the organisation of nudism events and new nudist groups and associations (see http://federacionnudistademexico.org).

\section{Methods}

\section{Approach}

According to Li and Petrick's (2006) review of the relevant literature, research on festival and event motivations has been dominated by quantitative methods. The exception to this are studies that have conducted in-depth interviews, such as the foundational research on event motivations undertaken by Crompton (1979) or the investigation of motivation factors prevalent among festival volunteers conducted by Barron and Rihova (2011). However, the majority of studies on festival and event motivations from the beginning until recently - have administered surveys to large samples (Chang \& Yuan, 2011; Crompton \& McKay, 1997; Lee, Lee, \& Wicks, 2004; Matheson, Rimmer, \& Tinsley, 2014; Uysal, Gahan, \& Martin, 1993). Quantitative approaches to research on festival and event motivations are likely to predominate as researchers continue to call for the creation of "universal" scales for measuring festival and event motivations ( $\mathrm{Li}$ \& Petrick, 2006). Nonetheless, Li and Petrick (2006, p. 244) state, "the involvement of more researchers with more diverse backgrounds and disciplinary approaches, and the employment of new research methodologies are strongly encouraged". A broader range of methods is thus needed to develop a fuller theoretical understanding of festival and event motivations.

Qualitative methodologies applied in contexts not yet studied - including nudist events - can yield a more profound and contextualised insights into festival motivations. Qualitative research facilitates the examination of subjects in depth. It provides unique tools for studying what lies behind or underpins decisions, attitudes, beliefs, perceptions, motivations and their connections with behaviours, experiences or other social phenomena and the contexts in which they occur (Ritchie, 2003). The cited author argues that exploratory and descriptive research based on qualitative approaches can facilitate mapping the range of elements, dimensions, classes or positions within social phenomena. These approaches can help researchers identify the nature or features of phenomena and describe the meaning that individuals attach to experiences, events or other phenomena, as well as develop and define typologies. Therefore, the present 
study adopted a qualitative approach to gain a deep, detailed and contextual understanding of what lies behind nudist tourists' motivations to attend the nudist festival in question.

\section{Informant selection}

A total of 24 semi-structured interviews were conducted with nudist festival visitors during the first week of February 2017. Some potential informants were first contacted through the FNM. The study's aims were explained to the FNM's president, who gave his approval and support before nudists planning to attend the festival were invited to participate in the study. Two weeks before the festival, the invitation was sent out through the FNM's social networks - including Facebook - to both FNM members and non-members within Mexico and abroad. Individuals willing to participate replied to the invitation immediately, after that, interviews were scheduled through Messenger and emails, as well as telephone calls and messages. These interviews were conducted right before and during the festival. Other informants were contacted on site through snowball sampling, while, interestingly, additional informants asked to participate on their own initiative.

\section{Instrument and interviews}

Legard, Keegan, and Ward (2003) indicate that, although the purpose of in-depth interviews is to understand informants' perspectives, the researcher plays an important role by guiding the interview process to meet the objectives of the research more effectively. To ensure this would happen, a semi-structured interview guide was designed. The guide was made up of four sections. The first sought to examine informants' perspectives on social nudity. The second section aimed to identify reasons for attending the festival, exploring both intrinsic (i.e. individual) and extrinsic (i.e. festival) factors. The third included questions focused on revealing nudists' travel and tourism patterns. The last section gathered sociodemographic information including gender, age, education, occupation, marital status and sexual orientation.

Nine interviews were conducted at the informants and researcher's hotels while the rest of the interviews took place on the beach (eight) or in restaurants (seven); the place for interviews depended on the informants' availability. Twenty-one interviews were conducted in Spanish and two in English (one Canadian informant spoke Spanish very fluently, and she asked to be interviewed in Spanish). The study's aims and the interview structure were explained in detail to each informant, and the interviewees gave their consent to be recorded.
Although some informants said revealing their real name was not a problem, total anonymity was promised.

Each interview was transcribed verbatim. The motivation factors listed by Maeng et al. (2016) were used as a starting point for the data analysis, which sought to identify, extract and classify nudists' motivations into categories by major festival motivation factors. Each interview was analysed individually and subjected to a motivation thematic analysis. Informants' responses were associated to festival motivations such as socialisation, escape, festival attraction and relaxation, as reported in the literature. Because motivations to participate in festivals and tourism are often intertwined, participants' responses were also analysed in terms of tourism motivation themes. The motivations identified were then grouped into seeking and escaping categories and into personal and interpersonal level to identify motivational factors and experience level, respectively. The analysis was undertaken considering the language in which each interview was undertaken. For the Spanish interview extracts reported in this paper, special effort was made not only to translate literally but to interpret and keep participants' original meaning.

The interview transcripts were also analysed and interpreted in terms of the informants' context to identify possible new motivation factors based on interviewees' own voice, experiences and subjectivities. This was done in order to not only identify nudists' motivations according to the factors found, named and categorised in previous research but also to provide the flexibility and possibility for new categories to emerge. This process also facilitated uncovering different meanings assigned to those factors already reported in existing studies. The resulting motivation factors were then analysed using the escape-seeking dichotomy.

\section{Findings \\ Nudists' sociodemographic profiles}

One of this study's main objectives was to examine the nudist festival attendees' sociodemographic profiles. Unlike Andriotis's (2016) study, in which $90 \%$ of the sample were men, the present sample included an almost equal number of women and men: 11 women and 13 men. The sample was not purposefully stratified by gender, but the study sought to include both women and men's voices, especially because the proportional inclusion of women and men was considered necessary given that tourism and other social phenomena are experienced differently depending on individuals' gender (Kinnaird, Kothari, \& Hall, 1994). 
Most informants (20) defined themselves as nudists and reported that they are often involved in nudist activities. Others did not consider themselves nudists because of the relatively short time they had practised this behaviour or because they did not like being labelled. The youngest informant was in her 20s, while the oldest was in his 70s. Most informants (21) were Mexicans and came from large urban cities such as Mexico City and Guadalajara, while others were from Canada and the United States.

Seventeen interviewees had a university degree, three a master's and one a doctorate. The data analysis also revealed that nudists have varied and multiple occupations. Participants included, among other professions, a homemaker, a businessman, a lawyer, a psychologist, an artist, two retirees and various teachers. Almost half (15) of the interviewees were single, seven were married and half of the informants had at least one child. Although two interviewees had been nudists for less than a year, the rest had practised nudism for various years or decades - even, in the case of one informant, his entire life.

The presence of diverse gender identities and sexual orientations has been repeatedly reported by research on public nudist spaces (2016; Andriotis, 2010; Douglas et al., 1977; Jaurand, 2005; Schoemaker, 2006). Schoemaker (2006) found evidence that, on nude beaches, individuals develop and play out different sexual scripts, postures and identities. The coexistence of various sexual and gender identity components in the nudist population, including those attending festivals, was corroborated by the present study. When asked about their sexual orientation, 16 participants defined themselves as heterosexual, but alternative responses and labels were explicitly given. These included, for example, "bi-curious", "nonheterosexual", "100\% masculine", "multifaceted", "basically heterosexual" and "everything".

Identities - as is the case for many other intrinsic constructs - are socially and subjectively defined (Eliason, 1996; Lawler, 2008), and, as can be seen by the above responses, identities do not always fit into predetermined categories found in the literature or predefined by researchers. Thus, studies that adopt a predetermined quantitative instrument may significantly deny informants the chance to express their subjectivities through their own constructs. To some extent, the present findings concur with the sociodemographic characteristics of natourists reported by Andriotis (2016). However, the current results reveal that nudists' sexual orientation and identities - perhaps like individuals in many other social groups - are quite diverse and self-defined, so these characteristics need to be captured through emic approaches.

\section{Motivation factors of nudist festival attendance}

This study's second objective was to examine motivation factors of nudist festival attendance and their relationship with tourism motivations. This had a double purpose. On the one hand, the aim was to explore further Maeng et al.'s (2016) conclusion that tourism motivation factors should not be applied to or used to understand festival motivations. On the other hand, this study sought to corroborate whether Andriotis's (2016) concept of natourism is also applicable not only to the general sociocultural and tourism context of the present research but also to the specific case of a nudist festival.

The study's results offer a clearer understanding of this setting's complex amalgamation of both festival and tourism motivation constructs. For most informants, the festival's planned activities (e.g. body painting, theatre plays and talks) were irrelevant to their decision to attend the nudist festival. A 40-year-old male who has practised nudism for four years claimed, 'I did not come for the festival; as a matter of fact, I don't know what the festival programme is, I'm not interested in it. I just came to have a good time with my friends'. A 38-year-old woman who has been a nudist for ten years similarly said: 'I know about the festival, but my visit was a matter of coincidence. I came to Zipolite because it's a nice place and you can be naked on the beach and meet new friends'. For those going exclusively to enjoy the event, the main motivation factor was the chance to socialise. In contrast to the quantitative approaches applied in previous studies, the qualitative approach adopted here facilitated further exploration of this socialisation component. On an interpersonal level, the festival offered nudists a unique chance to be with like-minded people - with individuals who share the same or similar views on nudism and the "textile" ${ }^{1}$ world. Many nudists from different parts of Mexico know each other either through the FNM or their own social networks. Some have become genuine friends, and, because distance does not allow them all to gather often, many attended the festival to meet their nudist friends. For many, the festival was the only chance to spend time with them. In addition, nudists wanted to meet other nudists and thereby expand their nudist social networks.

The qualitative approach used also allowed other festival motivation factors to emerge that had not been reported in the literature. Altogether, the informants were convinced of the psychological and social benefits of nudism, so these individuals believed that naturist philosophy needs to spread. Thus, due to social disapproval of nudism, another important festival motivation was to promote and support a naturist lifestyle. They viewed the event as an 


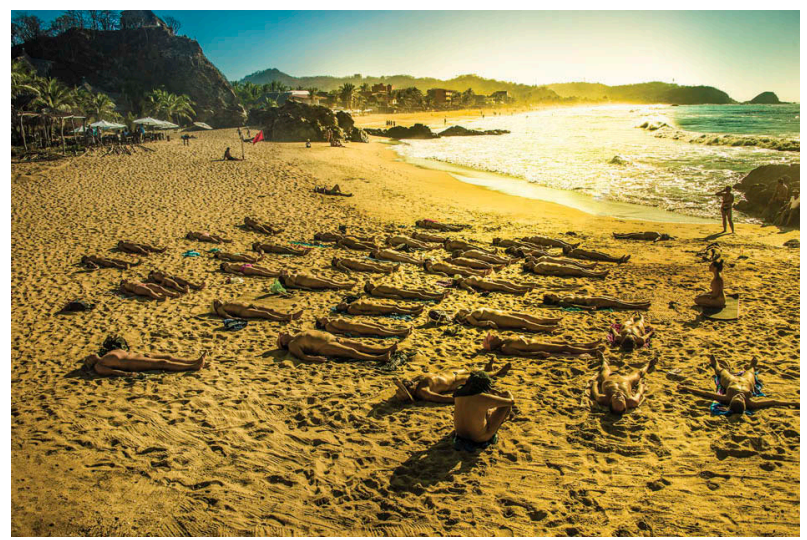

Figure 1. Zipolite Nudist Festival 2017 (photo by Juan Castañeda)

opportunity to show "textiles" what nudism is really about, including its benefits, and, consequently, to break associated stereotypes (see Figure 1). This was more of a collective than an individual motivation factor.

On an individual level, learning about and participating in a nudist lifestyle were significant motivations. Learning had two components: finding out about other nudists' experiences and views and, mainly for new nudists, acquiring knowledge about nudism (i.e. philosophies, practices, members and events). Most informants reported that nudism allows individuals to take off social labels and show who they really are. In this sense, some nudists attended the festival to explore their true self further - without social labelling - and to participate in a lifestyle that, due to social disapproval and a lack of spaces dedicated to social nudity, is conditioned by time and space.

In order to explore the festival's pull motivation components, interviewees were explicitly asked what attributes specific to this festival and unlike other events were relevant to their decision to attend. Nudism as the festival's core component was the most important attribute as this is the only festival in Mexico with the central theme of nudism. The festival thus offers visitors the chance to participate in an event in which, for many attendees, nudism is the norm. Throughout the year, nudists organise and attend other events in Mexico and abroad (e.g. yoga and family gatherings). These events often take place on a regional, local or interfamily level, but they are usually relatively small scale. Thus, the festival's potential for concentrating larger number of nudists was considered a significant reason for attending. A 66-year-old male nudist who has practised nudism for twenty years said, 'to me the festival is the opportunity to have a good time and share experiences with many more nudists than those whom I meet in other events throughout the year'.

Similarly, the festival's inclusiveness character was a specific pull factor for festival attendees. The interviewees reported that other nudist events are exclusively for nudist couples or families, and no single nudists can attend. This exclusion prevents some nudists - particularly those whose partner or family are not nudists and even entirely disapprove of nudism - from being part of such events. This nudist festival's policy of being open to the general public and its unconditioned character offered these individuals the chance to attend and participate regardless of whether they attended alone or with a partner, family or friends, contributing to an overall feeling of inclusiveness. A male participant who attended the festival for the first time claimed, 'unlike other events, the festival offers inclusiveness. Other events are exclusive for couples, mom and dad, for example, and do not allow single men or women'.

\section{Tourist motivation factors and their association with festival motivations}

Attending the festival was clearly the main reason for some nudists' visit. For others, however, the festival was just one more motivation factor for holidaying. Given that Zipolite is the only nude beach in Mexico or at least perceived as the only one by most informants, this destination is an important attractor for nudist tourists all year long. Regardless of the festival, many nudists gather in Zipolite at the beginning of each year. Through their social networks, nudists - especially those who are friends agree to meet in Zipolite and spend their holidays together on the nudist beach. The 2017 festival's dates coincided with the time of year when some nudists normally travel to the event-hosting destination, so they decided to participate in the festival while on holiday. A 43-year-old who has been a nudist for twenty-five years said, 'at this time of the year many nudists meet in Zipolite, so I came to the festival because it is the only chance that I have to meet my nudist friends; it's the only time in which we can all get together'.

This situation offered an opportunity to explore the relationships between festival and tourism motivations. To further understand this association, the push and pull motivation factors for those holidaying in Zipolite at the time of the festival were also explored. For those whose main presence was explained not by the festival itself but by their holiday in Zipolite, three main tourist motivation factors were identified. Similar to those interviewees whose main reason was attending the festival, social interactions emerged as the most important push motivation factor for visiting the destination at that time of the year. As mentioned above, some nudists, through their friendship networks, agreed to meet at this destination. Their main reason is thus also socialising but mainly among friends, unlike the festival attendees to whom the expansion of their nudist social 
networks is a major component. The interviewees on holiday viewed the festival more as a chance to strengthen friendships with like-minded nudists rather than to meet new people.

Participating in a chosen nudist lifestyle was also found to be a major motivation factor for these tourists. They travel to practice nudity in a non-restrictive environment in which they can experience freely their preferred way of being. A 37-year-old woman who has visited four times the destination said,

'what I like the most about Zipolite is that I can be naked all the time; food is good and local people are kind, but I enjoy this place because, unlike other places in which attitudes towards nudists are negative, I can get naked here and nothing happens'.

Since this motivation was also found for the festival attendees, this suggests that both festivals and tourism may offer nudists similar or the same chances to express their thoughts freely and enjoy their alternative lifestyle. Last, rest and relaxation were also reported as motivations. However, unlike Andriotis's (2016) finding that the most significant motivation factors for natourists were naturism, relaxation and stereotypical ancillary travel motivations, relaxation while being able to stay nude was secondary to these tourists' need to socialise and be nude.

From a pull motivation perspective, three main characteristics of the destination were reported as important when making travel decisions. The first is that the destination allows nudism. The possibility of being nude all the time is highly valued by nudist travellers. The second characteristic is the destinations' natural elements (i.e. beach and good weather), and the food was also reported as a reason to choose this destination. Although not considered overly important, the festival was seen as a special event offered by the destination, becoming itself a pull motivation factor for tourists.

\section{Discussion}

Using a qualitative approach, this study sought to explore nudist tourists' motivations for attending a nudist festival. Its findings and main contributions are discussed below in terms of previous theoretical and conceptual propositions regarding motivations and nudism.

Maeng et al. (2016, p. 22) concluded that "studies on festival attendance motivation should reflect the unique characteristics of festival motivation and should deal differently with tourism motivation". However, festivals are diverse in terms of type, theme and scale, so some festivals may be more tourist-oriented than others and their tourism dimension can be explained by tourist motivation theory. The present study demonstrated that, contrary to Maeng et al.'s (2016) assertion, tourism motivation factors can be quite useful to explain festival and event motivations. The current results reveal that, due to the prominent tourism components (i.e. psychological and social) of the festival in question and its close association with the tourism pull factors of the host destination, festival motivations can be explained through tourist motivation theory.

Notably, this study found that, in some cases, it is not easy - neither in theory nor in practice - to disentangle tourism dimensions from festival motivation factors. Cases in which one or more specific motivation factors, whether push or pull, are shared by both the festival and the event-hosting destination simultaneously show the difficulty and perhaps impossibility of studying these factors separately. The results thus suggest that tourism motivations can - and should - strongly inform the understanding of event motivations and vice versa.

Tourism is a constantly changing phenomenon, so its conceptual bases always need to be developed further. Andriotis (2016) proposed the concept of natourism, which comprises travel in which motivations are naturism, relaxation and stereotypical ancillary travel motivations such as local cuisine, social interactions with locals, exploration and shopping opportunities. The present study corroborated that, for tourists attending a nudist festival, nudism, socialisation and relaxation are major intrinsic motivation factors. The local community's permission for visitors to remain nude and the destination's natural and cultural elements are important extrinsic factors. Andriotis's (2016) concept of natourism together with this study's findings provide further evidence that tourism and nudist activities, particularly at festivals, can or even should be explained interdependently.

Both the escape-seeking dichotomy and push-pull framework also provided valuable insights in this study. The push and pull framework facilitated identifying the specific festival's components and internal psychological factors for attending a nudist festival, which together explain why tourists attend the festival under study. The escape-seeking dichotomy proved to be a useful theoretical framework for understanding motivations in terms of individuals' desire to escape difficulties and seek rewards on both personal and interpersonal levels in a nudist festival context (see Figure 2).

From an escape-seeking perspective, motivation factors for attending a nudist festival appear to be more significant on an interpersonal level. Leaving behind collective difficulties such as social disapproval of nudism and negative stereotypes of nudists comprises the primary force behind escape motivations. The search for socialisation, a sense of belonging to a social group and 


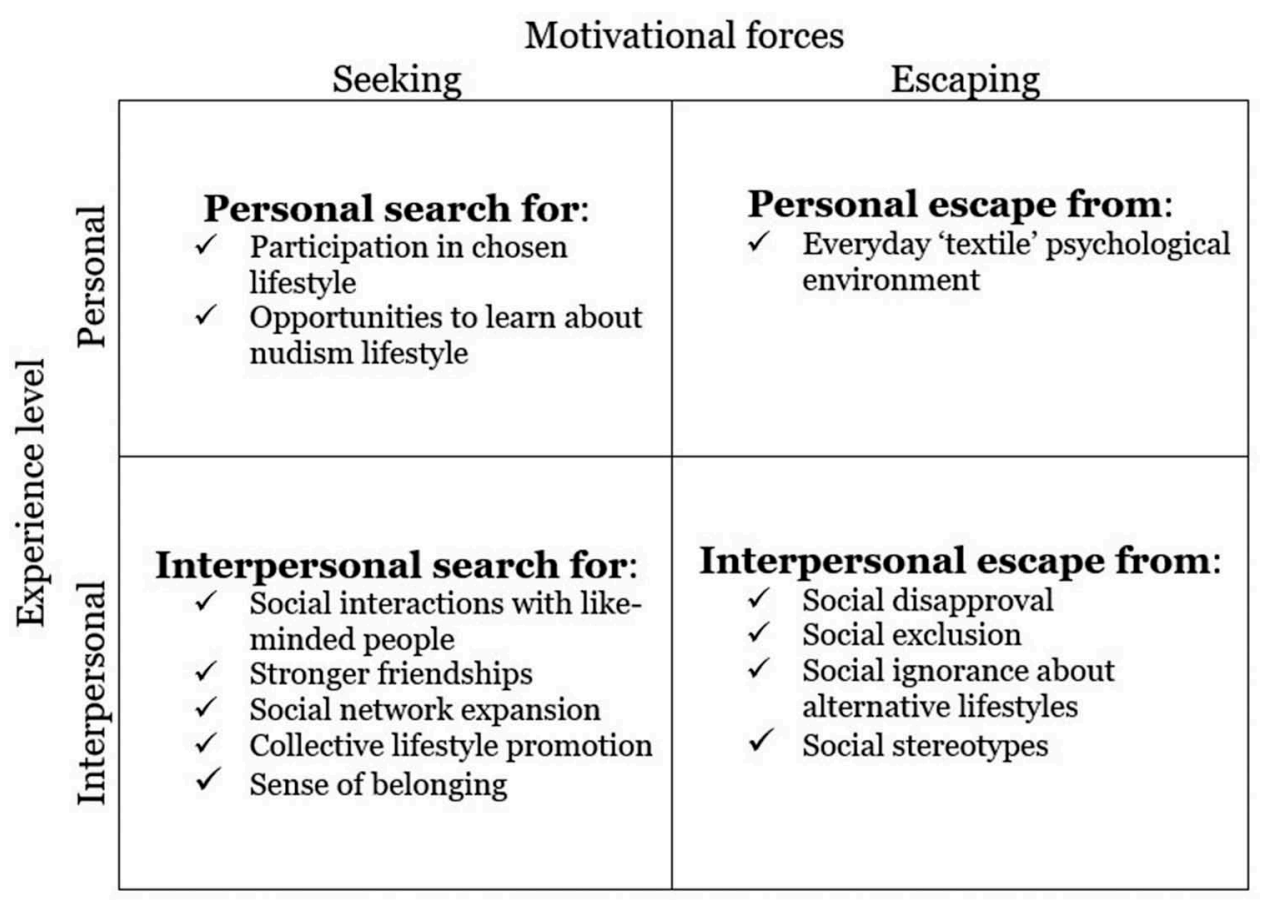

Figure 2. Matrix of major motivation factors of nudist festival attendance

the promotion of nudism as a collective lifestyle comprise most of the search dimension. The importance of a collective understanding in nudism motivation factors was noted on various occasions during the fieldwork since most participants referred more often to "us" rather than "me" and to "we, the nudists", and "they, the textiles". Therefore, this study's results suggest that attending nudist festivals depends more on motivations that are not so much individually as collectively significant to nudists as a self-differentiated social group.

\section{Conclusion}

This study's findings include the conclusion that, in contrast to Maeng et al.'s (2016) argument, tourism motivation factors can be extremely useful when seeking to explain festival and event motivations, especially for festivals with a strong tourism component. Importantly, evidence was found that tourism dimensions cannot be easily disentangled from festival dimensions in motivation studies.

In addition, the results show that, for nudist event attendance, the collective dimensions of motivation factors are quite significant. While individual psychological rewards such as participating in a chosen lifestyle partly explain festival attendance, interpersonal escapes and rewards comprise the largest part of motivations for nudist travel and festival attendance. The collective dimension of escape-seeking forces can be strongly associated with social disapproval and condemnation of nudists as a social group. Through attending festivals or destinations addressing the needs of this group, individuals have the chance to be who they really want to be and express their lifestyle collectively, away from social and clothing constraints.

Thus, support was found for the conclusion that festivals can be quite significant in terms of offering individuals interpersonal rewards. Other socially disapproved, discriminated or stigmatised groups, such as homosexuals, could also receive benefits from festivals. In special events, these groups may find a place to experience albeit only temporarily - who they truly are and construct a collective sense of celebration and social integration.

The findings of this study in terms of interpersonal motivation factors have managerial implications for nudist festivals. Festival offerings should seek to address more closely the collective benefits sought by the nudist community, including building and strengthening their collective identity. Activities that reinforce the sense of 'we, the nudists', can make festivals more attractive. Based on the present findings, activities facilitating social interactions with friends, colleagues and new members are more likely to lead to attendees' satisfaction. In addition, nudist festivals' marketing strategies need to promote the collective environment of these events. This will likely increase not only the number of nudist visitors, thereby strengthening a sense of community among them, but also make this alternative lifestyle more visible to "the textiles". 
This study's findings are exploratory, so they should not be generalised to other nudist communities without due caution. In addition, these findings may not be applicable to festivals in other sociocultural contexts and with a less prominent tourism dimension. These limitations, nonetheless, offer opportunities for further research. Other methodological approaches to research on the Zipolite and other nudist festivals may corroborate, reject or complement the findings presented here. How satisfied nudist festival attendees are overall and how and why local individuals get involved in nudist festivals are other questions to be addressed by future studies.

\section{Note}

1. "Textiles" is a term nudist informants used to refer to non-nudists.

\section{Acknowledgements}

The author would like to express his deepest gratitude to nudist informants for their invaluable participation in this study.

\section{Disclosure statement}

No potential conflict of interest was reported by the author.

\section{ORCID}

Carlos Monterrubio (D) http://orcid.org/0000-0002-3706-4644

\section{References}

Andriotis, K. (2010). Heterotopic erotic oases. The public nude beach experience. Annals of Tourism Research, 37(4), 1076-1096.

Andriotis, K. (2013). The 'antinomian' travel counterculture of Gavdos: An alternative mode of travelling. Annals of Tourism Research, 40, 40-58.

Andriotis, K. (2016). From nudism and naturism tourism to "natourism": Defining natourism and exploring natourists" motivations. Tourism Analysis, 21(2-3), 237-249.

Barcan, R. (2015). Nudism. In P. Whelehan \& A. Bolin (Eds.), The international encyclopedia of human sexuality (pp. 1-3). New Jersey: Wiley-Blackwell.

Barron, P., \& Rihova, I. (2011). Motivation to volunteer: A case study of the Edinburgh international magic festival. International Journal of Event and Festival Management, 2(3), 202-217.

Barthe-Deloizy, F. (2003). Géographie de la nudité. Etre nu quelque part. Paris: Bréal.

Carter, V. (2018, June 11). World naked bike ride - London [Video file]. Retrieved from https://www.youtube.com/ watch?v=wkSTPVZf-j0
Chang, W., \& Yuan, J. (2011). A taste of tourism: Visitors' motivations to attend a food festival. Event Management, 15(1), 13-23.

Clarke, M. (1982). Nudism in Australia. Victoria: Deakin University Press.

Crompton, J. L. (1979). Motivations for pleasure vacation. Annals of Tourism Research, 6(4), 408-428.

Crompton, J. L., \& McKay, S. (1997). Motives of visitors attending festival events. Annals of Tourism Research, 24(2), 425-439.

Daley, C. (2005). From bush to beach: Nudism in Australasia. Journal of Historical Geography, 31, 149-167.

Dann, G. M. S. (1977). Anomie, ego-enhancement and tourism. Annals of Tourism Research, 4(4), 184-194.

Douglas, J., Rasmussen, P., \& Flanagan, C. (1977). The nude beach. California: SAGE Publications.

EFE. (2017, February 05). Concluye festival nudista en playa Zipolite. El Universal. Retrieved from http://www.eluniversal. com.mx/articulo/estados/2017/02/5/concluye-festivalnudista-en-playa-zipolite

Eliason, M. J. (1996). Identity formation for lesbian, bisexual, and gay persons: Beyond a "minoritizing" view. Journal of Homosexuality, 30(3), 31-58.

Fisher, R. J., \& Price, L. L. (1991). International pleasure travel motivations and post vacation cultural attitude change. Journal of Leisure Research, 23(4), 555-581.

Getz, D. (2010). The nature and scope of festival studies. International Journal of Event Management Research, 5(1), 1-47.

Hanqin, Z. Q., \& Lam, T. (1999). An analysis of mainland Chinese visitors' motivations to visit Hong Kong. Tourism Management, 20(5), 587-594.

Iso-Ahola, S. E. (1980). The social psychology of leisure and recreation. Dubuque IA: W. C. Brown Company Publishers.

Iso-Ahola, S. E. (1982). Toward a social psychological theory of tourism motivation: A rejoinder. Annals of Tourism Research, 9(2), 256-262.

Jaurand, E. (2005). Territoires de mauvais genre? Les plages gays. Géographie et Cultures, 54, 71-84.

Jaurand, E. (2006). Le tourisme naturiste en Méditerrannée: Entre interface et choc des civilisations. Bulletin de I'Association des Géographes Francais, 3, 331-340.

Jaurand, E., \& de-Luze, H. (2004). Ces plages ou les genres s'affichent? Les territoires du nu sur la Cote d'Azur. In C. Bard (Ed.), Le genre des territoires: Masculin, féminin, neutre (pp. 227-240). Angers: Presses de I'Université d'Angers.

Jurdana, D. S., Milohnic, I., \& Cvelic-Bonifacic, J. (2009). The features of the naturist camping. Tourism and Hospitality Management, 15(2), 177-192.

Kinnaird, V., Kothari, U., \& Hall, D. (1994). Tourism: Gender perspectives. In V. Kinnaird \& D. Hall (Eds.), Tourism: A gender analysis (pp. 1-34). London: John Wiley and Sons Ltd.

Lawler, S. (2008). Identity. Sociological perspectives. Cambridge: Polity Press.

Lee, C., Lee, Y., \& Wicks, B. E. (2004). Segmentation of festival motivation by nationality and satisfaction. Tourism Management, 25(1), 61-70.

Legard, R., Keegan, J., \& Ward, K. (2003). In-depth interviews. In J. Ritchie \& J. Lewis (Eds.), Qualitative research practice. A guide for social science students and researchers (pp. 138-169). London: SAGE.

Li, X. R., \& Petrick, J. F. (2006). A review of festival and event motivation studies. Event Management, 9(4), 239-245. 
Maeng, H. Y., Jang, H. Y., \& Li, J. M. (2016). A critical review of the motivational factors for festival attendance based on meta-analysis. Tourism Management Perspectives, $17,16-25$.

Mansfeld, Y. (1992). From motivation to actual travel. Annals of Tourism Research, 19(3), 399-419.

Matheson, C. M., Rimmer, R., \& Tinsley, R. (2014). Spiritual attitudes and visitor motivations at the Beltane fire festival, Edinburgh. Tourism Management, 44, 16-33.

Merrill, F., \& Merrill, M. (1931). Among the nudists: Early nudism. London: Lightning Source UK Ltd.

Monterrubio, C. (2019). Hosts and guests' social representations of nudism: A mutual gaze approach. Annals of Tourism Research, 75, 18-28.

Ritchie, J. (2003). The applications of qualitative methods to social research. In J. Ritchie \& J. Lewis (Eds.), Qualitative research practice (pp. 24-46). London: SAGE.
Schoemaker, J. (2006). Bare bodies, beaches, and boundaries: Abjected outsiders and rearticulation at the nude beach. Sexuality \& Culture, 10(4), 29-53.

Snepenger, D., King, J., Marshal, E., \& Uysal, M. (2006). Modeling Iso-Ahola's motivation theory in the tourism context. Journal of Travel Research, 45(2), 140-149.

Uysal, M., Gahan, L., \& Martin, B. (1993). An examination of event motivations: A case study. Festival Management and Event Tourism, 1(1), 5-10.

Uysal, M., Li, X., \& Sirakaya-Turk, E. (2008). Push-pull dynamics in travel decisions. In H. Oh (Ed.), Handook of hospitality marketing management (pp. 413-439). Oxford: Butterworth-Heinemann.

West, K. (2018). Naked and unashamed: Investigations and applications of the effects of naturist activities on body image, self-esteem, and life satisfaction. Journal of Happpiness Studies, 19(3), 677-697.

WNBR. (2006). World naked bike ride. Retrieved from http:// www.worldnakedbikeride.org/ 